\title{
CALCULATION OF THE DIRECTIONAL PATTERN OF THE ELECTRIC RADIATOR NEAR THE CIRCULAR CYLINDER
}

\author{
A.A. Badalova, badalova2011@mail.ru, \\ M.A. Fomina, Manisha96@list.ru, \\ D.S. Klygach \\ South Ural State University, Chelyabinsk, Russian Federation
}

\begin{abstract}
Calculation of radiation pattern of the electrical radiator over a circular cylinder is presented. Radiation pattern of the electrical radiator taking into account influence of circular cylinder is calculated by the method of mirrorings. The received results of calculation were compared to the results found by the numerical method in strict electrodynamic problem definition. Theoretical results are in good quantitative compliance with the experimental ones. The offered method allows to calculate radiation pattern of the electrical radiator over a circular cylinder quite simple.
\end{abstract}

Keywords: half-wave radiator; system of radiators; radiation pattern.

\section{Introduction}

Antennas modern radar and navigation systems, communication systems, radio and television broadcasting imposes high requirements for the specified requirements to the field of radiation in accordance with the parameters of electromagnetic compatibility. First of all it is connected with limited possibilities for the placement of antennas operating in overlapping frequency ranges and with the same polarization, in close proximity to each other, for example on masts, towers. The formation of the amplitude-phase distribution of the radiation field in the far zone must take into account the specified requirements as to the form of amplitude days in the vertical and horizontal planes (the width of the main lobe and sidelobe level), a given frequency band, polarization, and the influence of object position antennas.

Widely used in modern radar and navigation systems, communication systems, radio and television broadcasting received the electrical radiator an antenna. Electrical radiator y antennas used in the millimeter, centimeter, decimeter, meter and longer wavelength ranges up to super-long waves and represent rectilinear conductors or straight conductors of the system (antenna arrays) excited at certain points [1].

When using these antennas is very often in the place of installation are local objects that represent the various extended cylindrical objects, both metallic and dielectric (homogeneous and heterogeneous) mast support, belt tower, cable-growths, feeder trunks reduce, screens and structural elements of the fabric antennas. In this case, when calculating the radiation fields of these antennas it is necessary to consider the influence of local items.

\section{Classical solutions}

To locate a field of electrical radiation of the dipole antenna taking into account the influence of a circular metal cylinder, use the rigorous solution for the electrical radiator, located parallel to the axis of the cylinder (Fig. 1). Methods of calculation of the radiation field for this problem and the solution to this described in $[2,3]$

The classical solution was used for the full vector of the field produced by the field of an external source field and the scattering for arbitrary spherical coordinates of the observation point [4]. The solution in the form of an endless spectrum of cylindrical waves for the angle $\theta=\pi / 2$ is as follows:

$$
E_{z}=\frac{i I_{0}^{e} \cdot l \cdot k^{2}}{4 \pi \omega \varepsilon_{a}} \frac{e^{-i k R}}{R} \sum_{n=-\infty}^{\infty} \frac{\varepsilon_{n} i^{n} \cos n \varphi}{H_{n}^{(2)}(k a)}\left[H_{n}^{(2)}(k b) J_{n}(k a)-H_{n}^{(2)}(k a) J_{n}(k b)\right],
$$


where $J_{n}(k a)$ - the Bessel function of m order; $H_{n}^{(2)}(k a)$ - the Henkel function of kind 2 of $\mathrm{m}$ order; $k$-wave number; $\varepsilon_{n}$ - the number of Neumann, $\varepsilon_{n}=1$ when $n=0, \varepsilon_{n}=2$ when $n \neq 0$.
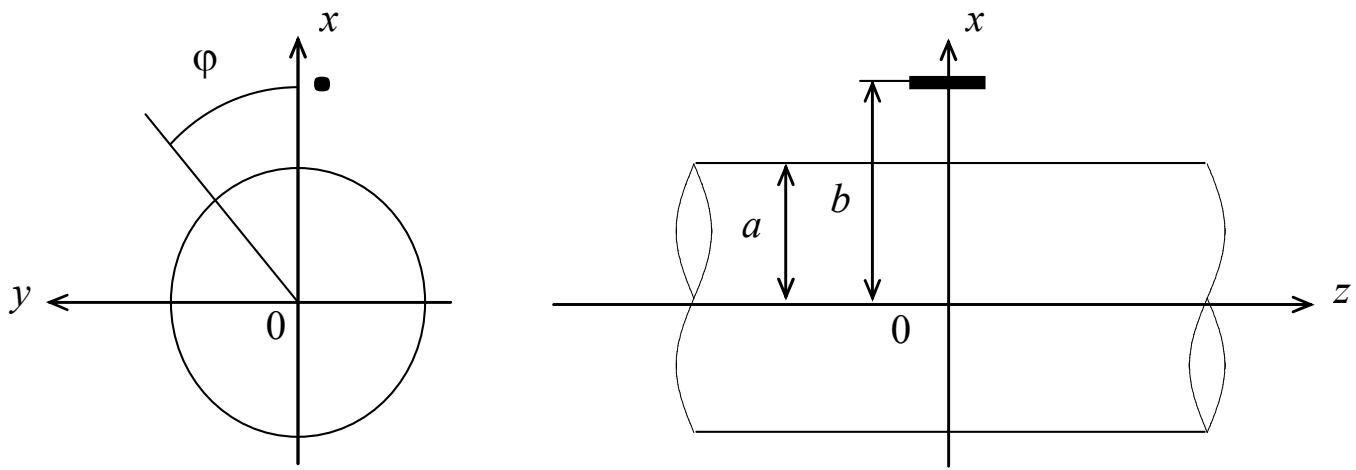

Fig. 1. The electrical radiator is parallel to the axis of the circular cylinder

Calculations was performed by formula (1) with an adaptive choice of the number summable spectral cylindrical components to provide the desired relative error of $10^{-6}$ calculations. In the analysis of the directional properties of the longitudinal dipole placed close to the cylinder, it follows that on the surface of the cylinder are excited by longitudinal currents only weakly flows into the shadow area. Therefore, the electromagnetic field in the shadow region decreases rapidly and does not have sharp oscillations, the nature of days is only weakly dependent on the cylinder diameter.

Calculate the direction diagram of electrical radiator located over a circular cylinder. We assume that the radius of the cylinder is equal to $a=0.3 \lambda$, and the distance from the cylinder axis to the electrical radiator $b=a+0.25 \lambda=0.55 \lambda$. The result of the calculation is shown in Fig. 2 .

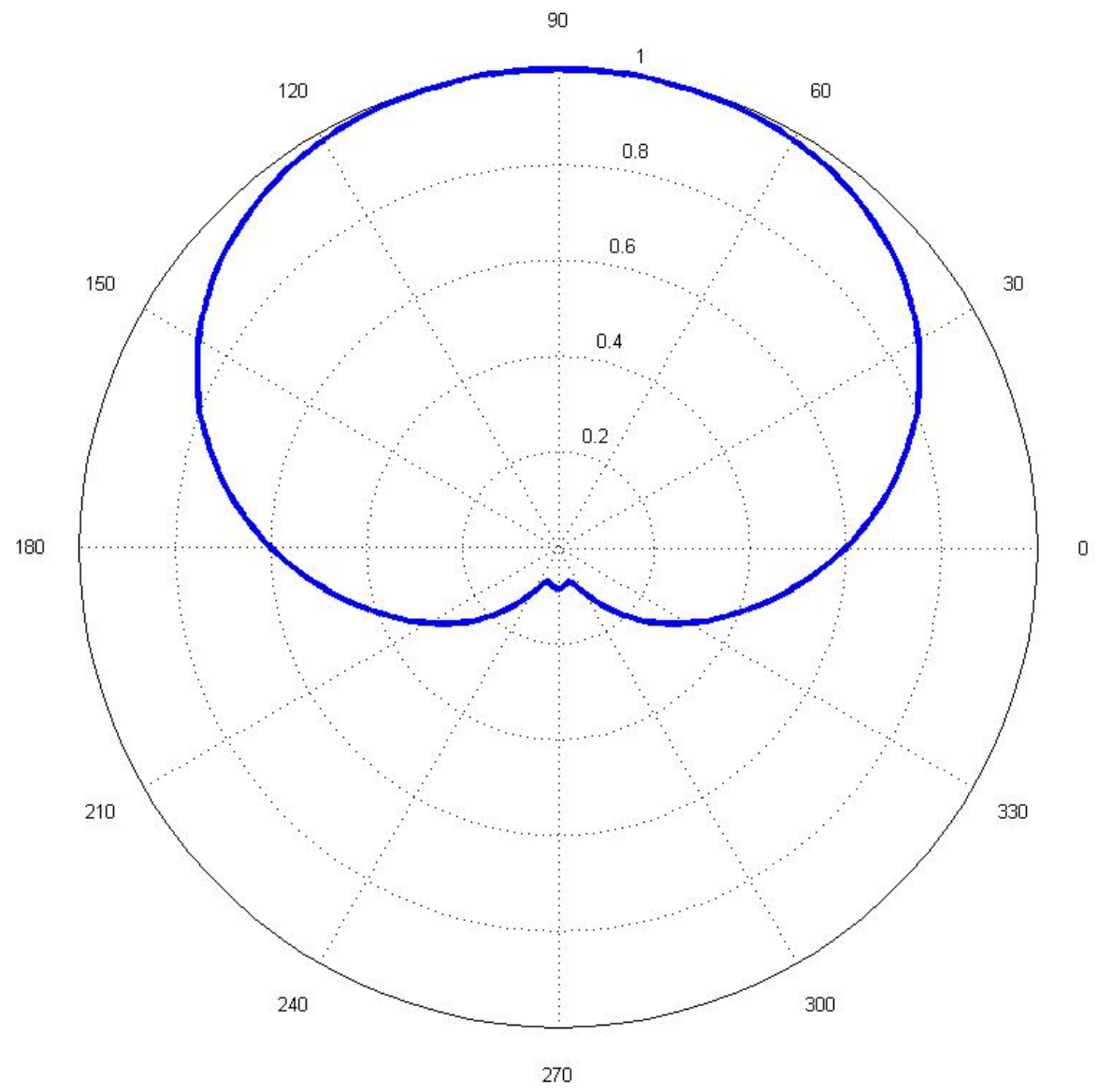

Fig. 2. The directional pattern of the electrical radiator located over a circular cylinder 


\section{Краткие сообщения}

But for engineering calculations performed during the installation of the antennas, does not require such precision in the calculation of the radiation field. In some cases, it is necessary to assess the possibility of installing the antenna without using the complex mathematical apparatus. The main goal in this case will be the installation of local effects. If the effect will be negligible, in this case, you can perform a more accurate calculation. If the magnitude of the impact will be enormous and for installing the antenna you will need to spend additional money on installation and eliminate the effect, in this case, the exact calculation to perform is not necessary.

\section{Solution}

For the estimated calculation, assume the witness [5]. Suppose that the radius of the cylinder is approximately a lot greater than the radius of the electrical radiator and the wavelength i.e. $a>\lambda$. In this

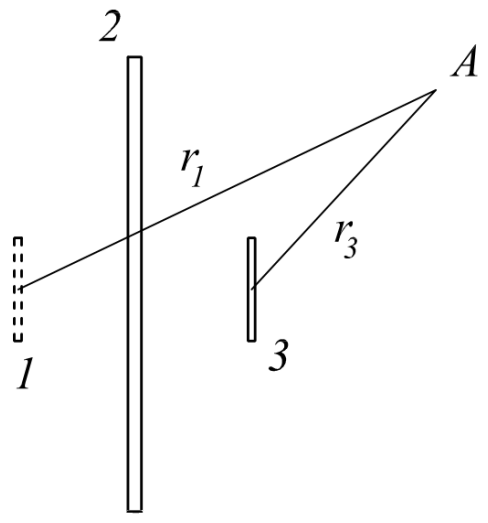

Fig. 3. The location of the electrical radiator and the circular cylinder: 1 - mirror; 2 - circular cylinder; 3 - the real source case, a cylinder with a radius of curvature of the cylinder can be neglected and represent a cylinder in the form of reflecting a perfectly conducting plane. Replace the reflector, using the method of mirror images, the mirror source. Then the radiation field of the electrical radiator is raised over a circular cylinder can be represented as the total radiation field from two electrical radiator $s$ at a distance of $2 b$ from each other (Fig. 3).

Because now deals with the system of two transducers, the distance between them is equal to $2 b$. Far field for the antennas is determined by the formula:

$$
r=\frac{D}{\lambda},
$$

where $D-$ is the largest overall dimension of the antenna; $\lambda$ - wavelength.

Because the decision deals with half-wave electrical radiator s, $D=\lambda / 2$. Substitute $D=\lambda / 2$ in the formula (2), we get that the radius of the far zone is equal to $1 \mathrm{~m}$. the Distance between the electrical radiator $s-2 b$. Assume that $b>3 \lambda / 2$, we get that $2 b>7 \lambda$. In this case, we can assume that the sources are in the far zone of the other.

Then the radiation field of the real and mirror source in the far zone can be represented by the formula:

$$
E=E_{0} e^{-i k r} \frac{1}{r}
$$

where $E_{0}-$ is the initial amplitude of the field; $r$ - is the distance from the point source to the observation point.

Then the total field can be represented as the sum of the fields from the real and mirror source. The mirror source, which describes the reflected wave, it is necessary to consider that the phase of the wave from the mirror source must be different by $90^{\circ}$ from the phase of the mirror source.

In Fig. 4 shows the radiation pattern of the electrical radiator, raised over a circular cylinder. It is seen that the calculation results for the strict solution, the proposed method of calculation coincide well with the experimental results in the range of angles $0-90^{\circ}$ and $270-360^{\circ}$.

The difference between the results obtained with the classical solution, the proposed method for angle range $90-270^{\circ}$ can be explained by the fact that simple solution takes into account the curvature of the cylinder. In the method of calculation, due to the fact that the reflected field from the cylinder is represented by the mirror source, it is assumed that the reflecting surface is smooth. 


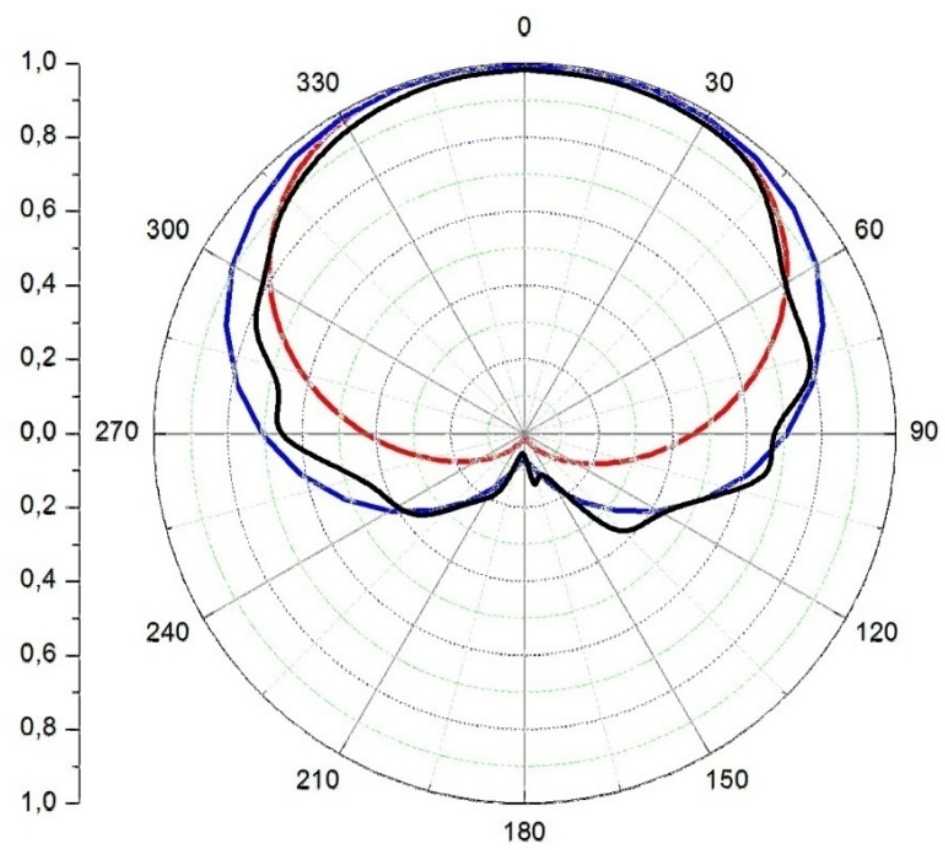

Fig. 4. The directional pattern of the electrical radiator, raised over a circular cylinder
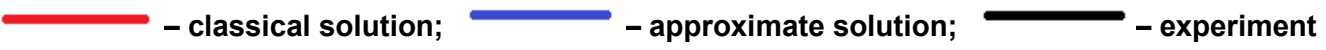

\section{Conclusion}

Thus, the performed theoretical and experimental calculation of the radiation pattern of the electrical radiator, raised over a circular cylinder. It is assumed that the diameter of the circular cylinder is equal to $a>\lambda$ larger than the wavelength, the length of the electrical radiator does not exceed one wavelength in free space. Using the proposed calculation method, the calculated radiation pattern of the electrical radiator over a circular cylinder. The results obtained agree well with the rigorous solution. Theoretical and experimental results are in good quantitative accordance.

\section{References}

1. Khashimov A.B. Matematicheskie modeli v proektirovanii antennykh system [Mathematical Models for Antenna Systems Design]. Chelyabinsk, South Ural St. Univ. Publ., 2015. 160 p.

2. Ilyinsky A.S., Kravtsov V.V., Sveshnikov A.G. Matematicheskie metody elektrodinamiki [Mathematical Models of Electrodynamics]. Moscow, Vysshay Shkola Publ., 1991. 224 p.

3. Mitra R. (Ed.) Vychislitel'nye metody v elektrodinamike [Computing Methods in Electrodynamics]. Moscow, Mir Publ., 1977. 488 p.

4. Ayzenberg G.Z., Yampolsky V.G., Tereshin O.N. Antenny UKV: v 2 ch. Ch. 1 [VHFs Antennas: in 2 p. P. 1]. Moscow, Svyaz' Publ., 1977. 384 p.

5. Voitovich N.I., Khashimov A.B. [On the Correspondence of Asymptotic Solutions to 2D and 3D Problems in Antenna Engineering]. Journal of Communications Technology and Electronics, 2010, vol. 55, no. 12, pp. 1374-1379. (in Russ.)

Received 5 March 2017 


\title{
РАСЧЕТ ДИАГРАММЫ НАПРАВЛЕННОСТИ ВИБРАТОРА, ПОДНЯТОГО НАД КРУГОВЫМ ЦИЛИНДРОМ
}

\author{
А.А. Бадалова, М.А. Фомина, Д.С. Клыгач \\ Южно-Уральский государственный университет, г. Челябинск
}

\begin{abstract}
Представлен расчет диаграммы направленности полуволнового излучателя, поднятого над круговым цилиндром. Диаграмма направленности полуволнового излучателя с учетом влияния кругового цилиндра рассчитана с помощью метода зеркальных отражений. Полученные результаты расчета сравниваются с результатами, найдеными численным методом в строгой электродинамической постановке задачи. Теоретические результаты находятся в хорошем количественном соответствии с экспериментальными результатами. Предложенный в статье способ позволяет просто вычислить диаграмму направленности полуволнового излучателя с учетом влияния кругового цилиндра.

Ключевые слова: полуволновый излучатель, система излучателей, диаграмма направленности.
\end{abstract}

\section{Лuтература}

1. Хатимов, А.Б. Математические модели в проектировании антенных систем: моногр. / А.Б. Хашимов. - Челябинск: Издат. иентр ЮУрГУ, 2015. - 159 с.

2. Ильинский, А.С Математические модели электродинамики / А.С. Ильинский, В.В. Кравиов, А.Г. Свешников. - М.: Высшая школа, 1991. - 224 с.

3. Вычислительные методы в электродинамике / Под ред. Р. Митры. - М.: Мир, 1977. - 488 c.

4. Айзенберг, Г.3. Антенны УКВ: в 2 ч. / Г.3. Айзенберг, В.Г. Ямпольский, О.Н. Терешин. - М.: Связь, 1977. - Ч. 1. - 384 с.

5. Войтович, Н.И. О соответствии асимптотических решений двумерных и трехмерных задач в антенной технике / Н.И. Войтович, А.Б. Хашимов // Радиотехника и электроника. - 2010. T. 55, № 12. - C. 1471-1476.

Бадалова Арина Алимамедовна, студентка Высшей школы электроники и компьютерных наук, Южно-Уральский государственный университет, г. Челябинск; badalova2011@mail.ru.

Фомина Мария Андреевна, студентка Высшей школы электроники и компьютерных наук, Южно-Уральский государственный университет, г. Челябинск; Manisha96@list.ru.

Клыгач Денис Сергеевич, канд. техн. наук, доцент кафедры конструирования и производства радиоаппаратуры, Южно-Уральский государственный университет, г. Челябинск; klygachds@ susu.ru.

Поступила в редакцию 5 марта 2017 2.

\section{ОБРАЗЕЦ ЦИТИРОВАНИЯ}

Badalova, A.A. Calculation of the Directional Pattern of the Electric Radiator near the Circular Cylinder / A.A. Badalova, M.A. Fomina, D.S. Klygach // Вестник ЮУрГУ. Серия «Компьютерные технологии, управление, радиоэлектроника». - 2017. - Т. 17, № 3. C. $142-146$. DOI: $10.14529 /$ ctcr170316

\section{FOR CITATION}

Badalova A.A., Fomina M.A., Klygach D.S. Calculation of the Directional Pattern of the Electric Radiator near the Circular Cylinder. Bulletin of the South Ural State University. Ser. Computer Technologies, Automatic Control, Radio Electronics, 2017, vol. 17, no. 3, pp. 142-146. DOI: $10.14529 /$ ctcr170316 